\title{
Challenges in Education System Affecting Teacher Professional Development in Oman
}

\author{
By Amira Sulaiman Al Shabibi ${ }^{*}$ \\ Heikki Silvennoinen ${ }^{+}$
}

\begin{abstract}
On international comparisons, the development of Oman's education system in terms of the increase in educational enrolment rates and in the level of teacher qualifications has been remarkably rapid. Almost $100 \%$ access to basic education has been achieved, and almost all students progress onto post-basic education. A report from the World Bank in 2001 described the development of Oman's education system in the decades 1970-2000 as "unprecedented" and "unparalleled by any other country". However, international assessments on learning outcomes in literacy (PIRLS), and mathematics and sciences (TIMSS) show that Omani students perform very poorly in all three subjects, and that boys' performance levels are significantly lower than that for girls. The aim of this study is to describe the present-day situation in Omani schooling and the challenges it poses for teacher professional development. The study is based on a meta-analysis of a variety of studies, research reports, articles, and statistics with the aim of presenting a comprehensive picture of the challenges for the development of teaching and learning in Omani schools.
\end{abstract}

Keywords: gender, learning outcomes, Oman, teaching, teacher professional development.

\section{Introduction}

Oman is located in the Middle East, bordered by the United Arab Emirates, Saudi Arabia, and Yemen. In 2017, the estimated population of Oman was 4.74 million. A large share of the population are foreigners, about 600,000 people, mostly guest workers from Egypt, Pakistan, India, Bangladesh, and the Philippines. (Oman Population, 2017).

According to the Human Development Report of 2010, of all nations included in the report the Sultanate of Oman showed the fastest progress in the Human Development Index. Since 1970 Oman has witnessed a rapid evolution from a very poor to a very rich country, e.g., with a quadrupling of gross enrolment and literacy rates and a 27 -year increase in life expectancy (United Nations, 2010).

On international comparisons, the development on Oman's education system in terms of increased enrolment rates and more highly qualified teachers has been remarkably rapid. Almost $100 \%$ access to basic education has been achieved, and almost all students progress onto post-basic education. A report from the

${ }^{*}$ Curriculum Officer in English Language, Specialized Centre for Professional Training of Teachers, Oman.

${ }^{\dagger}$ Professor in Sociology of Education, University of Turku, Finland. 
World Bank in 2001 described the development of Oman's education system in the years 1970-2000 as "unprecedented" and "unparalleled by any other country" (Al Balushi \& Griffiths, 2013).

Three stages can be identified in the development of Oman's education system. The first stage, from 1970 to the mid 1990's, created the educational infrastructure to increase educational access to all parts of the country. The second stage, from the mid 90's onwards, introduced reforms to improve the quality of the education system. The third phase, currently in progress, focuses on reviewing and evaluating the system with the aim of improving student outcomes.

In 1970 there were only three schools and 30 teachers in Oman. All 900 students were boys. In 1970 only $56.1 \%$ of men and a mere $11.7 \%$ of women were literate. By 2014 there were 1,042 government schools, with 516,891 students being educated by 55,343 teachers. Now, half of the pupils in schools are girls.

In the early 1970's half of the teachers held qualifications of a lower level than the equivalent of a General Certificate of Secondary Education (GCSE) and only $8 \%$ possessed a university degree. Now, over $83 \%$ of teachers have completed a bachelor degree-level qualification or higher (Ministry of Education, 2016).

Despite the progress in student access and in teacher qualifications, the school system continued to exhibit poor student outcomes. Reports and studies highlight a number of factors for this. The first is that the curriculum being taught is overcrowded and heavily content-laden, making the means of delivery narrow and dull (New Zealand Education Consortium, 2013). The second is the need for teacher training that is more practical rather than just academic, preparing new teacher students for the whole role of a teacher (World Bank, 2012). There is also a severe lack in the use of student-centred learning approaches, with teachers continuing to show a preference towards teacher-centred learning. Finally, assessment is almost exclusively concerned with summative purposes with little emphasis being devoted to formative assessment (University of Cambridge, 2010).

Along with other countries in the MENA region (Middle East and North Africa) Oman is facing educational problems which can be seen as an educational crisis. There are three converging factors that make up the crisis: an increase in the educational disparity within countries, a relative decrease in the quality of education despite high per capita education expenditures, and a mismatch between labour market needs and the output of educational systems (Chapman \& Miric, 2009; United Nations, 2002).

\section{School System in Oman}

The Basic Education programme was introduced in 1998 and was phased in to replace the General Education system. The old General Education system was made up of three stages: Elementary (grades 1-6), Preparatory (grades 7-9) and Secondary (grades 10-12). At the Secondary stage, students followed either an Arts or a Science stream. The new Basic Education system runs from grades 
1 to 10, and is divided into two stages: Cycle One (grades 1-4) and Cycle Two (grades 5-10). In Cycle 1 schools, the people of the staff are all female, and boys and girls are taught together in the same classroom. In Cycle 2 and Post-Basic Education (grades 11 and 12), schools are all single-sex schools catering for either boys (taught by male staff) or girls (taught by female staff). Post-Basic Education is the equivalent of high school in other countries and all school pupils are expected to progress to this stage. At the end of grade 12 pupils sit a national standardized test and learning outcomes from Grade 12 determine access to university and other post-school study specialisations.

Diagram 1. Structure of General Education (until 1998) and Basic Education/ Post-Basic Education (1998 onwards) in Oman

\begin{tabular}{|c|c|c|c|}
\hline \multicolumn{2}{|c|}{ General Education until 1998} & \multicolumn{2}{|c|}{$\begin{array}{l}\text { Basic Education and Post-Basic Education } \\
1998 \text { onwards }\end{array}$} \\
\hline Grade level & Stages & Grade level & Stages \\
\hline 12 & \multirow{3}{*}{ Secondary } & 12 & \multirow[t]{2}{*}{ Post-Basic } \\
\hline 11 & & 11 & \\
\hline 10 & & 10 & \multirow{6}{*}{$\begin{array}{l}\text { Basic Education } \\
\text { (Cycle Two) }\end{array}$} \\
\hline 9 & \multirow{3}{*}{ Preparatory } & 9 & \\
\hline 8 & & 8 & \\
\hline 7 & & 7 & \\
\hline 6 & \multirow{6}{*}{ Elementary } & 6 & \\
\hline 5 & & 5 & \\
\hline 4 & & 4 & \multirow{4}{*}{$\begin{array}{l}\text { Basic Education } \\
\text { (Cycle One) }\end{array}$} \\
\hline 3 & & 3 & \\
\hline 2 & & 2 & \\
\hline 1 & & 1 & \\
\hline
\end{tabular}

Source: Ministry of Education, 2008b.

\section{Research Problem and Data}

The aim of this article is to describe the present-day situation in Omani schools and the measures taken by the government to improve teaching and learning.

The research questions of the study can be stated as follows:

1. What are the factors behind the low average level of learning outcomes?

2. What are the challenges of the low learning outcomes pose for pedagogies, teaching methods, and teachers' skills?

3. What is the present-day situation with regard to teacher professional development in Oman and what measures have been taken to address the challenges teachers face?

The study is based on a meta-analysis of a variety of studies, research reports, articles, and statistics with the aim of presenting a comprehensive picture of the challenges that need to be addressed in order to develop Omani schooling. 


\section{Learning Outcomes}

Although Oman has carried out the steps required to expand its educational access, it has been ineffective in improving standards of learning. In the Programme for International Reading Literacy Study (PIRLS) and the Trends in International Maths and Science (TIMSS), young Omanis are performing at a level well below students in top-performing countries in the crucial subjects of language, mathematics and science. In fact, Oman is not a stand-alone anomaly among the Middle East and North African countries. In several developing countries with a relatively high expenditure on education international assessments have revealed that only a small percentage of young people are able read well, write well, and solve mathematical problems (Pritchett, 2013).

The impact of family background (i.e. economic, social and cultural capitals of family) on children's educational attainment is frequently proved throughout the Western world (e.g. Bourdieu, 1984; Breen \& Jonsson, 2005; Erikson \& Goldthorpe, 1993; 2002; Ermisch, Jäntti \& Smeeding, 2012; Lareau \& Conley, 2008; Savage, Warde, \& Devine, 2005; Shavit \& Blossfeld 1993; Weis, 2008). Many studies have confirmed that besides socio-economic background, gender is an important factor in determining school success and failure, with girls often outperforming boys. A study among Omani girls (aged 6-13 years) reveals a strong association between parental education levels and school failure. Fathers' and mothers' illiteracy and low educational levels is much more common among girls with school failure than in other groups (Al-Sharbati, Al-Adawi, Al-Lawativa, \& Al-Hussaini, 2005).

Results from the TIMSS and PIRLS assessments in 2011 provide deeper insights on the performance of Omani students in mathematics, science and reading. As shown in Table 1, only $20 \%$ of Omani students reached the "intermediate" skill level, which can be regarded as minimum acceptable level in a modern society; this compared to the international average of $69 \%$. At the high end, 5\% of Omani students reached the "high" level, and only 1\% of Omani students were regarded as "advanced" in maths. More than half (54\%) of Omani students were below the "low" level, whereas only $10 \%$ of the international student population fell into this category. TIMSS assesses student proficiency across three types of cognitive skills: knowledge recall, the application of knowledge in solving problems, and the ability to reason in working through problems. Omani students did not perform well in any of these three dimensions. The results are similar in mathematics and science, and at both grades 4 and 8 (TIMSS Math, 2011; Ministry of Education, 2016). 
Table 1. International Benchmarks for TIMSS in Grade 4 Mathematics, and for PIRLS in Grade 4 Reading in 2011: Percentage of Students at four Proficiency Levels in Oman, Hong Kong, and Singapore (cumulative \%)

\begin{tabular}{|l|c|c|c|c|}
\hline Assessment/Country & $\begin{array}{c}\text { Advanced } \\
\text { (625 and above) }\end{array}$ & $\begin{array}{c}\text { High } \\
(\mathbf{5 5 0}-\mathbf{6 2 4})\end{array}$ & $\begin{array}{c}\text { Intermediate } \\
\mathbf{( 4 7 5 - 5 5 4 )}\end{array}$ & $\begin{array}{c}\text { Low } \\
\mathbf{( 4 0 0 - 4 7 4 )}\end{array}$ \\
\hline TIMSS & & & & \\
\hline Hong Kong & 37 & 80 & 96 & 99 \\
\hline Singapore & 43 & 78 & 94 & 99 \\
\hline International average & 4 & 28 & 69 & 90 \\
\hline Oman & 1 & 5 & 20 & 46 \\
\hline PIRLS & & & & \\
\hline Hong Kong & 18 & 67 & 93 & 99 \\
\hline Singapore & 24 & 62 & 87 & 97 \\
\hline International average & 8 & 44 & 80 & 95 \\
\hline Oman & 0 & 5 & 21 & 47 \\
\hline
\end{tabular}

Similarly PIRLS includes international benchmarks for four performance levels. Not one single student from Oman was rated "advanced", and only 5\% were in the "high" category; in comparison, $44 \%$ of students in the international sample achieved a score at these levels. More than half (53\%) of Omani students failed to attain the basic reading level (the "low" benchmark), while only $5 \%$ of the international sample and a mere 3\% in Singapore and 1\% in Hong Kong failed to reach this level. Four processes are assessed in the PIRLS test: detailed information retrieval, making straightforward inferences, interpreting and integrating ideas and information, examining and evaluating content, language and textual elements. It is quite revealing that Omani students perform particularly poorly in answering the higher order items testing interpretation, integration and evaluation (PIRLS 2011; Ministry of Education 2016).

The priority for the Ministry of Education (2016) is to ensure that the educational system enables the great majority of students to demonstrate basic competencies in mathematics, science and reading by achieving a score at the "low" and "intermediate" levels. However, there is also a challenge at the top end of performance. There are not enough top performers in Oman.

Seeing that all its citizens are given the same educational opportunities has been a goal since the beginning of the "Omani Renaissance" in 1970. Despite the efforts, regional and, in particular, gender gaps in learning outcomes remain. Gender gaps have important implications on the well-being of the country as a whole. The gender gap has been widening in many skill domains, and the performance of Omani boys in mathematics and science has declined substantially between 2007 and 2011 (TIMSS Math, 2011, 80; TIMSS Science 2011, 77). The TIMSS 2007 study showed that at grade 8, girls outperformed boys in mathematics by 54 points, which is the largest difference between genders among the 48 participating countries, while in science, girls outperformed boys by 61 points. In 2011 the gender differences in mathematics and science have grown wider (see Table 2). 
Table 2. The Difference Between Girls and Boys in Test Score Points at the $8^{\text {th }}$ Grade as Measured in TIMSS 2007 and 2011 (Girls Minus Boys)

\begin{tabular}{|l|c|c|c|c|}
\hline & \multicolumn{1}{|c|}{ Mathematics } & \multicolumn{2}{c|}{ Science } \\
\hline & 2007 & 2011 & 2007 & 2011 \\
\hline International average & 5 & 4 & 6 & 6 \\
\hline GCC countries & \multicolumn{4}{|l|}{} \\
\hline Oman & 54 & 63 & 61 & 78 \\
\hline Qatar & 38 & $(11)$ & 70 & 26 \\
\hline Bahrain & 32 & 43 & 62 & 59 \\
\hline Saudi Arabia & 23 & $(15)$ & 43 & 26 \\
\hline Kuwait & 22 & n.a. & 49 & n.a. \\
\hline Middle East and North Africa (non-GCC) & \multicolumn{5}{|l|}{} \\
\hline Palestinian National Authority & 36 & 23 & 36 & 27 \\
\hline Jordan & 20 & 28 & 34 & 43 \\
\hline Syria & -16 & $(-11)$ & -9 & $(-6)$ \\
\hline Egypt & 13 & n.a. & 17 & n.a. \\
\hline Lebanon & -13 & -12 & $(-7)$ & $(-4)$ \\
\hline Iran & $(7)$ & $(7)$ & $(12)$ & $(5)$ \\
\hline Algeria & -5 & n.a. & $(1)$ & n.a. \\
\hline High Performing Countries & \multicolumn{5}{|l}{} \\
\hline Japan & $(-4)$ & $(-8)$ & $(-4)$ & -8 \\
\hline Korea & $(-4)$ & -6 & -8 & $(-5)$ \\
\hline Singapore & 15 & 9 & $(8)$ & $(-1)$ \\
\hline
\end{tabular}

$(\mathrm{x})=$ difference between gender not statistically significant

When assessing the difference between the performance of boys and girls in reading (PIRLS, 2011), the international differential is 16 points. By comparison, Oman has a gender differential rating of 40 points in favour of girls, the second highest differential of all the participating countries. On the grade 12 Diploma examinations, the results show that the pass rate for girls was 9 percentage points higher than for boys (Ministry of Education, 2016).

According to the World Bank Report (2012) this significant performance difference can be traced to a number of factors. 1. There are differences experienced by girls and boys in both the home and school environment; 2 . Girls generally use their time at home more effectively in preparation and studying in comparison to boys. Compared to boys, grade 8 girls tend to spend less time watching television or videos or playing computer games, and more time reading books for enjoyment or doing homework. 3. Despite their poor results, boys do not lack self confidence in their abilities. Boys may think that they are better than they actually are and therefore maybe do not feel any need to improve their performance.

Although girls outperform boys in every educational schooling level (61\% of graduates are female), only $25 \%$ of females are participating in the workforce, compared to $77 \%$ of males. Consequently, the workforce of Oman is predominantly made up of those who have performed less well educationally (Ministry of Education, 2016). 


\section{Challenges and Recent Developments}

A small scale interview study targeted on lecturers from College of Education, College of Art and the Language Centre at Sultan Qaboos University lists several areas of development in curriculum, teaching methods and assessment: 1. the major problem that school curriculum is facing is in its application in the schools. The curriculum does not satisfy the society's needs. There are good reasons to shift from the theoretical curriculum to a practical one. 2. Teachers do not apply the teaching methods they are taught and trained to apply in initial preparation. So, the effective methods are not actually used in teaching. Teachers should use methods that better fit the students' individual levels of performance and abilities. 3. The methods used to evaluate the students' performance have a direct effect on their performance. Tests and exams are not the best way to evaluate students' performance. There are good reasons to implement continuous assessment effectively. (Al-Maskri, Al-Mukhini, \& Amzat, 2012.)

\section{Curriculum}

The present curriculum for each subject and at each grade level is prescribed in student textbooks and teacher guides. When Oman had a shortage of qualified teachers, these arrangements helped to ensure curriculum coverage for all students across the school year. The New Zealand Consortium Report (2013) pointed out that teachers in Oman are now much better qualified and they should therefore be given more flexibility over what they teach and how. The report argued that this would encourage teachers to move away from a didactic approach and to make more use of differentiated teaching and learning techniques.

Both the World Bank Report (2012) and the New Zealand Consortium Report (2013) commented on the overcrowded nature of the school curriculum and the short school year in Oman. The curriculum includes too many subjects for the time available for them to be taught to the depth required for students to meet learning standards through the key stages of schooling. The CFBT/NFER study (2012) reported that most subjects put more emphasis on knowledge acquisition rather than retrieval and understanding. The study also pointed out that curriculum differentiation for students of differing levels of ability is limited in Oman.

Al-Jardani (2012) declared that the field of curriculum evaluation is still developing in Oman and a lack of a framework for curriculum evaluation in the Ministry of Education in Oman for the public had been observed. He pointed out that this has resulted in a miscommunication between the curriculum departments and the practitioner in the field.

\section{Pedagogy}

The Basic Education programme of 1998 introduced a student-centred learning approach as part of a pedagogical shift. This shift reflected widespread international pedagogical approaches in which students were seen as continuous 
learners, needing development in conceptual and critical intellectual skills (New Zealand Education Consortium, 2016).

Although teachers are expected to use a mix of teacher-centred and studentcentred methods, authorities support the use of the student-centred approach. This is to encourage a more appropriate learning pace for students, recognising the fact that students will often need a number of learning opportunities to meet the learning outcomes, and to engage students through individualised approaches to learning. Not all students learn in the same way or in the same learning duration. Adopting student-centred methods enables teachers to offer students learning tasks that are appropriate to their learning needs, and challenge their abilities. Student-centred approaches allow teachers to be flexible in their approach to teaching, to adjust the curriculum and the presentation of information to learners, rather than expecting students to modify themselves for the curriculum (Ministry of Education, 2016).

There has been significant efforts in promoting student-centred learning over the last decade in Oman. However, only a minority of teachers are competent in student-centred learning techniques as was acknowledged in the University of Cambridge report (2010). The New Zealand Education Consortium (2013) found that while teachers were familiar with student-centred learning techniques, many regarded them as something of a luxury. Teachers regarded their single most important objective being to ensure the completion of the syllabus and preparing their students for examination. At the same time, Ministry of Education (2016) emphasizes that teachers should promote active learning - where, e.g., the asking of questions is encouraged - and ensuring that knowledge and skills are taught in real life situations. Student-centred approaches would be particularly helpful in promoting inquiry learning and developing analytical and higher order skills.

\section{Assessment}

The World Bank Report (2012) commented on the Basic Educational reform of 1998 for introducing a wide range of curriculum assessment tools. The assessment tools used were prepared in a way that would suit every subject and include short written or oral tests, quizzes, performance assessment tasks, projects and portfolios. Students are to be actively involved in exploration and enquiry through task-based activities, and teachers are expected to gather achievement information from several sources. Moreover, feedback, both oral and written, is to be part of the day-to-day teaching process (Alsarimi, 2001). Continuous assessment, including both formative and summative tools and procedures, were introduced. Summative assessment is used to hold students accountable for their learning, while formative assessment is used to provide feedback on whether or not the student is grasping the material learned and to offer assistance to enable the student to meet the learning outcomes (Ministry of Education, 2016).

A major review of research papers on formative assessment found that it is capable of producing significant gains in student attainment levels (Black and Wiliam, 1998). However, both the Cambridge and the CFBT/NFER reports noted 
that teachers in Oman are almost exclusively using continuous assessment in a summative way to evaluate their students by awarding marks and grades, and are neglecting the formative aspects of addressing and assessing their students' weaknesses and strengths (CFBT/NFER study, 2012).

Both the World Bank Report (2012) and the New Zealand Report (2013) noted that the marks and grades awarded to students are too high and are not a true reflection of their achievement levels. For example, $27 \%$ of grade 8 students in mathematics and $32 \%$ in science received "excellent" or "very good" ratings in continuous assessment from their teachers; this compared with only $2 \%$ of grade 8 students in mathematics and $8 \%$ in science receiving an "advanced" or "high" rating on the 2007 TIMSS test. The reports point out that when students have inflated perceptions of their learning achievement levels they have little incentive to invest effort to achieve better results.

\section{Teachers}

After home background, the quality of teachers is generally regarded as having the most significant influence on student learning outcomes (OECD, 2005; Hattie, 2009). The successful implementation of educational reform is, therefore, largely dependent on the quality of the teaching force.

The World Bank Report (2012) found that many student teachers are not strongly motivated to be teachers, and they often apply for teacher education due to lack of career alternatives. As a result, many student teachers lack the required dedication for the profession. Teaching continues to be one of the most favoured options as a career choice for females in Oman. Partly, this is due to socio-cultural reasons, with teaching being viewed as an appropriate profession for women, but it is also due to the attractive work conditions including the salary and long holidays. However, the commitment level is still not satisfactory as many teachers, even female teachers, view teaching as a source of income and to be carried out with the minimum amount of effort. Some of the reasons behind this attitude are an insufficient interest in teaching, lack of support, and absence of an inspirational environment (Al Belushi, 2004). Clearly, teacher-training colleges need to revise their selection procedures to ensure that they attract the best and most motivated candidates (OECD, 2005).

The College of Education at Sultan Qaboos University (SQU) is the leading institution in Oman involved in the training of new teachers. However, SQU provides training for only about $15 \%$ of newly qualified teachers; the rest come from private institutions in Oman and institutions abroad. The variable standards in these institutions is a matter of concern and it is widely claimed that levels of subject knowledge and teaching skills of newly qualified teachers is dependent on which institution they have graduated from (World Bank, 2012). Between 1997 and 2005, Education Colleges located in six different regions in Oman provided teacher preparation courses awarding a bachelor degree. The colleges were transformed into Applied Sciences colleges and education as a specialisation was discontinued. Recently, however, increased demand meant that one of the colleges - Rustaq College - reintroduced some courses in education/teacher 
training.

Although most of the staff in the College of Education Faculty in SQU was trained as teachers, many were immediately selected for sponsored postgraduate programmes abroad and later returned to join the College. As a result, most have limited experience in teaching in a school setting. Similarly most of the educational staff at private universities is foreigners who were initially trained as teachers, but few have had careers teaching school-age students. These patterns have resulted in a theoretical lecture approach in education (World Bank, 2012).

An international review (McKinsey \& Company, 2007) of teacher education stressed the importance of increasing the amount of teacher training that takes place in real life settings in schools and classrooms. However, an international report (World Bank, 2012) conducted on Omani trainee teachers, shows that little of their training occurs in the classroom. In SQU, only $6 \%$ of the total course credits are accounted for teaching practice. Student teachers have teaching practice for one day per week in the $7^{\text {th }}$ semester and for two days per week in their final $8^{\text {th }}$ semester, and teacher practice is not offered at all during the first three years of the course. In Nizwa University, teaching practice accounts for only $5 \%$ of the total course credits. While in school, each student teacher works with a cooperating teacher, but as the World Bank Report (2012) suggested, the quality of supervision and support provided by cooperating teachers varies substantially. Al Shabibi (2013) who followed the experience of four novice English language teachers in Omani schools for a full academic year found that the teachers in the study thought that there is no close association between teacher preparation and the real teaching situation.

Newly qualified teachers typically report problems in the areas of classroom management, student motivation, student assessment and accommodating individual student differences (World Bank, 2012). Similar challenges faced by newly appointed teachers were found by Al Shabibi (2013): the key challenges faced by newly qualified Omani teachers are "a reality shock", classroom management, assessment of students' performance, pressure of workload and time management. Moreover, novice teachers lack support from appropriate professional training programmes and from induction programmes in particular. The novice teachers in the $\mathrm{Al} \mathrm{Shabibi} \mathrm{study} \mathrm{all} \mathrm{agreed} \mathrm{that} \mathrm{supporting} \mathrm{programmes}$ are rare and confined to induction meetings conducted for a few days at the very beginning of the year before they had started teaching and had experienced its challenges (Al Shabibi, 2013).

On the other hand, the study carried out by Alyahmadi \& Al-Kiyumi (2014) revealed a common belief among the study participants - teachers and evaluators - that the poor performance of teachers in schools is due to the lack of efficient implementation of the teacher evaluation process. This study highlighted the confidentiality, vagueness of standards and criteria for evaluation, and the overreliance on classroom observation as the main reasons behind this dissatisfaction (Alyahmadi \& Al-Kiyumi, 2014). 


\section{Recent Initiatives for Developing Education}

Poor learning outcomes of Omani students is a matter of great concern and the Ministry of Education is currently carrying out a series of initiatives in an attempt to transform not only pedagogies but the education system as a whole. The most fundamental are the following:

- Curriculum and performance standards are presently being developed. Standards will provide benchmarks for the educational levels and ranges of students of all ages and grades and will help to evaluate the performance of schools, students and staff.

- The Ministry of Education is presently developing professional standards for teachers, and staff involved with schooling. These standards will be an important development in helping to clarify roles, evaluating staff performance and developing methods for further improvement.

- A National Assessment Centre has been established to be responsible for the delivery of assessment and qualifications systems through the production of valid and reliable assessment instruments supported by high quality statistical analysis and research capabilities and an online platform for assessment.

- The recently established Specialised Centre for Professional Training of Teachers is to be responsible for the training of all staff that work in the education sector. The Centre aims to develop the skills and confidence and motivation levels of educators by providing sustained, intensive and accredited professional development.

A recent study based on questionnaires to school administrators (principals, their assistants, education supervisors, senior teachers) shows that school administrators are mostly very well aware of the core values of basic education of Oman. There is also a clear agreement among the school administrators on practices to spread these values in the school environment (i.e. values related to excellence, development, creativity, and quality) (Al-Ani, 2014). Along with school administrators, teachers are the gatekeepers of educational reform (Chapman \& Miric, 2009, 319). Teachers make the changes happen by helping the students make use of their full potential.

\section{Teacher Professional Development as Means for Change}

In rapidly changing societies initial teacher preparation does not sufficiently ensure effective and individually transforming teaching methods. This is one reason for the increase in the amount of theorising on teacher professional development. Teacher professional development in its numerous forms has been proved to have a significant positive impact on teachers' belief and practices, students' learning, as well as on the implementation of educational reforms (see e.g. Guskey, 1985; 2002; 2003; Ingvarson, Meiers, \& Beavis, 2005; Saunders, 
2013; 2014; Villegas-Reimers, 2002).

In Table 3 below we summarise the policy aims and empirical findings on central problems in Omani schooling, and the challenges these problems constitute to teacher professional development.

Table 3. Education Policy Aims, Evidence on Reality, and Challenges for Teacher Professional Development in Oman

\begin{tabular}{|c|c|c|}
\hline Education Policy Aim & Evidence on Reality & $\begin{array}{c}\text { Challenge for Teacher } \\
\text { Professional Development }\end{array}$ \\
\hline \multicolumn{3}{|l|}{ Learning Outcomes } \\
\hline $\begin{array}{l}\text { Attainment Levels } \\
\text { The principal aim of } \\
\text { the evaluation process } \\
\text { is to improve schools } \\
\text { so that they can attain } \\
\text { and maintain high } \\
\text { standards of students' } \\
\text { learning (MOE, 2008b) }\end{array}$ & $\begin{array}{l}\text { Results in TIMSS and PIRLS } \\
\text { show that students in Oman } \\
\text { have low performance levels. }\end{array}$ & $\begin{array}{l}\text { Provide courses for teachers } \\
\text { aimed at improving student } \\
\text { learning. } \\
\text { Train supervisors and senior } \\
\text { teachers on how to identify and } \\
\text { support low achieving teachers } \\
\text { and schools. } \\
\text { Deliver training programmes } \\
\text { for school principals focussing } \\
\text { on instructional leadership. }\end{array}$ \\
\hline $\begin{array}{l}\text { Equality between } \\
\text { genders } \\
\text { The concept of gender } \\
\text { equality is reflected at } \\
\text { policy and } \\
\text { implementation level } \\
\text { and the educational } \\
\text { activities enhance the } \\
\text { concept of gender } \\
\text { equality. (MOE, } \\
\text { 2009b) }\end{array}$ & $\begin{array}{l}\text { Assessment results show that } \\
\text { girls consistently outperform } \\
\text { boys in all subjects and across } \\
\text { all grade levels. }\end{array}$ & $\begin{array}{l}\text { Support male teachers to } \\
\text { develop instructional strategies } \\
\text { to improve motivation and } \\
\text { learning among boys. }\end{array}$ \\
\hline $\begin{array}{l}\text { Equality between } \\
\text { schools } \\
\text { A national goal of } \\
\text { Oman is to ensure that } \\
\text { all students are being } \\
\text { provided with high } \\
\text { quality education } \\
\text { regardless to their } \\
\text { gender, social status, } \\
\text { cultural group or area } \\
\text { of residence. (MOE, } \\
\text { 2008b) }\end{array}$ & $\begin{array}{l}\text { There are wide variations in } \\
\text { the performance of schools. }\end{array}$ & $\begin{array}{l}\text { Training programmes will } \\
\text { achieve impact by working with } \\
\text { teachers from all schools. } \\
\text { Teachers will be encouraged to } \\
\text { adopt collaborative practices to } \\
\text { improve teaching and learning, } \\
\text { and school cluster groups will } \\
\text { be established to help spread } \\
\text { good practice. }\end{array}$ \\
\hline $\begin{array}{l}\text { Equality between } \\
\text { regions } \\
\text { The ministry believes } \\
\text { that education can help } \\
\text { to increase both } \\
\text { regional equality and } \\
\text { equality among all } \\
\text { individuals. (MOE, } \\
\text { 2008b) }\end{array}$ & $\begin{array}{l}\text { Student performance is lower } \\
\text { in the more remote and less } \\
\text { populous regions. }\end{array}$ & $\begin{array}{l}\text { Every school in the Sultanate is } \\
\text { targeted by the professional } \\
\text { development training } \\
\text { programmes held at the } \\
\text { SCPDT. } \\
\text { Applying workplace Training as } \\
\text { an essential component of } \\
\text { training. }\end{array}$ \\
\hline
\end{tabular}




\begin{tabular}{|c|c|c|}
\hline Pedagogy & & \\
\hline $\begin{array}{l}\text { Curriculum } \\
\text { One of the key } \\
\text { characteristics of the } \\
\text { new curriculum is that } \\
\text { it is comprehensive in } \\
\text { nature, not limited to } \\
\text { textbook knowledge, } \\
\text { and encompasses } \\
\text { experiences relevant to } \\
\text { the learner in order to } \\
\text { address the present and } \\
\text { future needs of } \\
\text { students. (MOE, } \\
\text { 2008b) }\end{array}$ & $\begin{array}{l}\text { Curriculum differentiation for } \\
\text { students of differing levels of } \\
\text { ability is limited. }\end{array}$ & $\begin{array}{l}\text { Train teachers on classroom } \\
\text { management techniques to } \\
\text { enable them to teach mixed- } \\
\text { ability classes. } \\
\text { Train teachers on how to } \\
\text { develop additional support } \\
\text { materials, e.g. scaffolded } \\
\text { lessons for differentiated } \\
\text { learning. }\end{array}$ \\
\hline $\begin{array}{l}\text { Assessment } \\
\text { The philosophy of the } \\
\text { new assessment system } \\
\text { is grounded on a range } \\
\text { of assessment } \\
\text { instruments, formative } \\
\text { as well as summative } \\
\text { use of assessment, with } \\
\text { continuous assessment } \\
\text { being given greater } \\
\text { focus in } \\
\text { assessment.(MOE } \\
2008 \text { a, 2009a, 2009b) }\end{array}$ & $\begin{array}{l}\text { Teachers provide } \\
\text { unrealistically high } \\
\text { assessments of the } \\
\text { performance of their students. } \\
\text { Teachers make little use of } \\
\text { formative assessment } \\
\text { techniques. }\end{array}$ & $\begin{array}{l}\text { Provide training on how to } \\
\text { reliably and consistently } \\
\text { moderate students' work. } \\
\text { Train and support all teachers in } \\
\text { the use of a range of assessment } \\
\text { instruments and in the use of } \\
\text { formative assessment } \\
\text { techniques. }\end{array}$ \\
\hline $\begin{array}{l}\text { Teaching methods } \\
\text { Among the } \\
\text { cornerstones of the } \\
\text { current reform are the } \\
\text { student - centred } \\
\text { approach and } \\
\text { cooperative } \\
\text { instructional strategies } \\
\text { (MOE 2008b, 2009a, } \\
\text { 2009b) }\end{array}$ & $\begin{array}{l}\text { Few teachers use effective } \\
\text { student-centred learning } \\
\text { methodologies. }\end{array}$ & $\begin{array}{l}\text { - Train teachers on how to } \\
\text { refocus their values and } \\
\text { expectations on effectively } \\
\text { catering for the needs of all } \\
\text { students. } \\
\text { - Train teachers on the use of } \\
\text { student-centred approaches and } \\
\text { the development of student- } \\
\text { centred teaching and learning } \\
\text { materials. }\end{array}$ \\
\hline \multicolumn{3}{|l|}{ Teachers } \\
\hline $\begin{array}{l}\text { Teacher preparation } \\
\text { High professional level } \\
\text { of all teachers with } \\
\text { practical know-how. } \\
\text { The Ministry of } \\
\text { Education has entered } \\
\text { into discussions with } \\
\text { the Omani pre-service } \\
\text { teacher training } \\
\text { providers in an attempt } \\
\text { to ensure that student } \\
\text { teachers receive } \\
\text { practical rather than } \\
\text { theoretical preparation } \\
\text { (MOE, 2008b) }\end{array}$ & $\begin{array}{l}\text { Different preparation } \\
\text { backgrounds for newly } \\
\text { qualified teachers. } \\
\text { Diverse preparation and } \\
\text { educational backgrounds for } \\
\text { expatriate teachers } \\
\text { Newly qualified teachers are } \\
\text { not adequately prepared for } \\
\text { the classroom. }\end{array}$ & 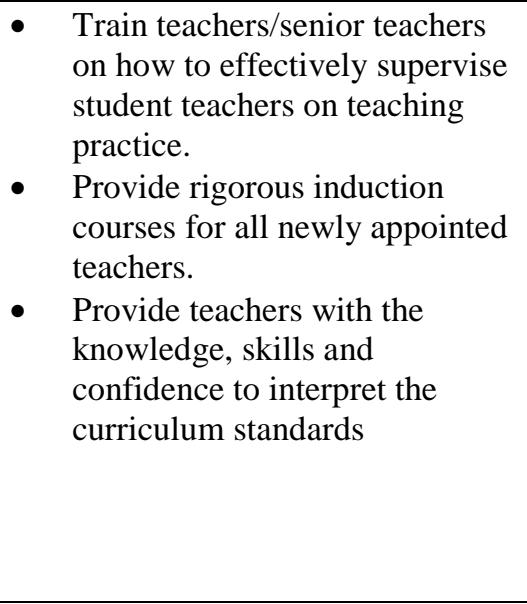 \\
\hline
\end{tabular}




\begin{tabular}{|c|c|c|}
\hline $\begin{array}{l}\text { Teaching profession } \\
\text { The main aim of the } \\
\text { in-service training } \\
\text { programmes is both to } \\
\text { help prepare teachers } \\
\text { before teaching in the } \\
\text { new reformed } \\
\text { environment and to } \\
\text { offer on-going support } \\
\text { when they are involved } \\
\text { in the reform process } \\
\text { (MOE, 2008B) }\end{array}$ & $\begin{array}{l}\text { The teaching profession has a } \\
\text { lack of status and there is a } \\
\text { lack of a teacher } \\
\text { professionalism and } \\
\text { accountability. }\end{array}$ & $\begin{array}{l}\text { Train teachers on how to } \\
\text { evaluate themselves against } \\
\text { professional standards. } \\
\text { Develop a teacher career } \\
\text { structure linked to professional } \\
\text { development and appraisal. }\end{array}$ \\
\hline $\begin{array}{l}\text { Equal competence by } \\
\text { gender } \\
\text { The efforts made by } \\
\text { the Sultanate to close } \\
\text { the gender gap were } \\
\text { recognized in the } \\
\text { United Nation } \\
\text { Children's Fund's } \\
\text { report, "The State of } \\
\text { the World's Children", } \\
\text { published in } 2003 \text {. } \\
(2008 \text { B) }\end{array}$ & $\begin{array}{l}\text { Many male teachers have } \\
\text { lower expectations of their } \\
\text { pupils compared to female } \\
\text { teachers. }\end{array}$ & $\begin{array}{l}\text { A focus of all in-service } \\
\text { training courses with male } \\
\text { teachers will be to ensure they } \\
\text { have similar learning } \\
\text { expectations as teachers in } \\
\text { girls' schools. } \\
\text { Facilitate cooperation between } \\
\text { female and male teachers/ } \\
\text { schools. }\end{array}$ \\
\hline
\end{tabular}

Despite various policy measures, learning outcomes have persistently remained low. The gap between policy aims and the realities of everyday school work is still wide. In the following we will discuss the ways in which teacher professional development can contribute to bringing about improved outcomes in relation to the curriculum, pedagogy and assessment.

\section{The Role of the Specialised Centre for Professional Training of Teachers}

The World Bank Report (2012) indicated that in a survey conducted in 2009 on 150 teachers in five regions, teachers' major criticisms of in-service training were as follows: 1. the training is over-theoretical with an absence of practical applications, 2. the training does not address issues which the participants' regarded as important, 3 . the trainers are not sufficiently knowledgeable of the content they deliver, 4 . the courses are too short to have a lasting impact on their teaching. The need for reorganising the concept of teacher professional development is evident and recognised by actors in the field.

There is also some concern that teachers do not always take professional development courses seriously as they have no implications for salaries or promotion. Furthermore, teachers are normally selected for training by supervisors, resulting in some teachers complaining that they are sent on irrelevant courses or courses on repeated topics (World Bank, 2012).

The Specialised Centre for the Professional Training of Teachers, which began operating in 2014, is playing a leading role in the Ministry of Education's reform programme. The main purpose of the Centre is to improve the quality of student learning and it aims to raise the level of learning outcomes through the 
professional development of the education workforce. At full capacity, up to 2,000 new teachers, 6,000 experienced teachers and 1,000 educational leaders will be following the Specialised Centre's strategic programmes of two years duration.

Training at the Specialised Centre started with five strategic programmes selected to address the most critical needs of Oman's education system, amongst which are the need to raise students' attainment in science, maths and language literacy, as identified by the TIMSS and PIRLS results. The five programmes were:

- Senior Teachers: 520 teachers - one from every school

- Arabic language: 200 teachers - one from every grade 1-4 school

- Mathematics: 374 teachers - one from every grade 5-10 school

- Science: 423 teachers - one from every grade 5-10 school

- Subject supervisors: 411 out of 1,500 subject supervisors

In 2015, the following two additional programmes were launched:

- New Teachers: 786 of the 860 teachers employed in 2014/2015

- 900 of the 960 teachers employed in 2015/2016

- School Leaders: 200 principals and vice principals - targeting $20 \%$ of schools

Two new programmes are to be started for the 2016/2017 academic year:

- English language: 800 teachers - targeting $80 \%$ of schools

- Field 2: 400 Mathematics and Science teachers - targeting $80 \%$ of grade 1-4 schools

Due to the "reality shock" faced by new teachers, the Specialised Centre has developed a comprehensive induction programme for all of its new teachers. The induction programme focuses on teaching and learning classroom practices, making the new teachers aware of what is expected from them in terms of professional standards, and raising awareness of the demands of the curriculum and assessment. Although professional standards can be used for appraisal purposes, their principal purpose is to support improvement. At the Specialised Centre, teachers are trained on how to use the standards as a self-assessment tool that will help to inform them on whether or not their work conforms to best practice, and to engage in planning and seek professional support to enable them to acquire new knowledge and skills (see Ministry of Education, 2016).

All teachers need to be provided with opportunities to break down the isolation of teaching and to collaborate with each other in order to drive their own improvement. Teachers need to be encouraged to engage in collaborative practice and to observe each other's teaching. The Specialised Centre has promoted the use of online platforms for teachers to talk to other teachers, beyond their own schools, and share ideas about their classroom practices. 
The Centre's programmes are designed to achieve sustainable change in the daily work of the participants. They are focused on the implementation, application and practice of the most up-to-date and effective methods of improving student outcomes. To secure direct impact on student standards, the following principles have informed the Centre's strategic programme design:

- Sustained one or two year programmes to embed knowledge, skills, qualities and values.

- Integrated face-to-face, online and workplace training.

- Inclusion of international best practice and research

- Inclusion of all Ministry of Education priorities and initiatives

- Quality assurance and endorsement by an outside organization for validation and accreditation (the Institute of Education in London).

The Centre aims at developing highly skilled, confident and motivated educators by providing sustained, intensive, accredited professional development. To maximise the impact, all schools in the country will be covered and a high proportion of teachers and regional officials will be reached. The centre aims to send a clear message to the profession and the wider public that improvements are a priority.

\section{Curriculum and Pedagogy}

The World Bank Report (2012) found that the current curriculum is overcrowded in terms of the content expected to be covered within the time available, and heavily prescribed in terms of what is to be delivered and the means of delivery. Establishing Curriculum Standards is regarded as a key mechanism in helping to address the current problems related to contentheaviness and over-prescription. It will also help to define and sequence the curriculum, and help to establish clear learning goals and assessment criteria (New Zealand Education Consortium, 2013).

Although professional development cannot influence the content of the curriculum, it can play a significant role in the effective implementation of the Curriculum Standards. Staff capacities need to be developed in order to translate the standards and incorporate them into effective teaching (New Zealand Education Consortium, 2013). Moreover, building and publicising a framework helps show the role and responsibilities of each actor in developing and evaluating the curriculum. This framework can also assist the process of providing a systematic curriculum evaluation to support practitioners in the field (Al-Jardani, 2012).

A mixed pedagogy approach has been encouraged in Oman's education system, although evidence from a number of evaluation reports shows that teachers require much more assistance in developing their skills to carry out student-centred learning. Student-centred learning demands an approach from teachers that focuses on improvisation and problem solving. It is known from international experience that this is something that requires high expertise (see 
Ministry of Education, 2016). The CFBT/NFER study (2012) concluded that "teachers have not had sufficient training to deliver the curriculum using a more student-centred approach and to foster crucial underpinning skills of analysis, enquiry and synthesis of information."

Delivering high-level instruction requires teachers to re-examine their attitudes on the expectations they have of their students. They need to believe that all their students are capable of improving their performance. To achieve this, teachers need to apply new classroom management techniques to enable them to adopt more flexible and creative teaching and learning approaches. They need to develop a sophisticated set of skills to be able to respond to the demand for individualised learning in classrooms containing students with different levels of ability. They need to be able to assess the strengths and weaknesses of each individual student they teach, select the appropriate instructional methods to help them to learn, and deliver instruction in a way which helps students build on their strengths and overcome their weaknesses (Ministry of Education, 2016).

Moreover, when learning is not taking place in their classrooms, teachers should desist from blaming the students (for lacking ability, being lazy or uninterested), but rather they should look at their own practices to see what needs to be changed. In other words, a cultural change needs to take place in classrooms in which the responsibility for a lack of learning shifts from the student to the teacher (New Zealand Education Consortium, 2013).

\section{Assessment}

For high quality learning outcomes to be achieved, it is crucially important to ensure that assessment is connected closely to the curriculum and pedagogy. In order for teachers to operate continuous assessment properly and, in particular, to deploy formative assessment techniques, they need a considerable amount of training (CFBT/NFER study, 2012). As a result, assessment should be an integral part of teacher professional development to enable teachers to both evaluate their own performance, and to reliably assess their students' performance.

At the Specialised Centre for Professional Training of Teachers assessment receives considerable focus. For example, the New Teacher Programme is a one-year blended programme integrating four face-to-face units, three online units and four workplace learning units. In Unit 1 Face-to-Face (F2F), the teachers are given a number of practical challenges to introduce the concept of formative assessment and to understand its purpose and role in the learning process. Following these activities, the trainers facilitate a discussion on the concepts "Assessment of Learning" and "Assessment for Learning". The trainer encourages self-reflection and uses questioning to model how to elicit specific feedback from participants in the activities and encourage richer analysis.

The practical immersion is followed up with further research by exploring international examples of recent formative assessment practice before identifying and consolidating the benefits of on-going formative assessment in the classroom. Back at school, teachers then complete a series of online activities related to 
self and peer assessment before applying new assessment strategies in their classroom practice during the Workplace Learning unit. This model of training is then applied to Module 2 where teachers are expected to provide concrete examples of applying formative assessment in their classroom practice. Through facilitated group work the teachers explore further methods and approaches to assessment and discover how to plan their teaching in direct response to their students' learning as the week unfolds.

How teachers/trainees are assessed is also given a vital consideration at the Centre. During the Face-to-Face sessions at the Centre, trainers model a range of straightforward and effective assessment tools to gauge the understanding of new concepts e.g. SWOT (Strengths, Weaknesses, Opportunities and Threats) PMI (Positives, Minuses and Interests), traffic lights,"thumbs up/thumbs down", talk partners and smiley faces. Reflective time is built into each day of the F2F programme and following paired or group work discussions, teachers present their findings and observations in various formats to their peers to consolidate and extend their understanding of the new concept or strategy being introduced.

Back at school, teachers complete a Workplace Learning programme where they apply the formative assessments strategies explored at the F2F and discovered in the online tasks. Trainers use formative assessment to measure the input and understanding of the teachers during the F2F programme before assessing the Module 1 and Module 2 summative reports that enable teachers to reflect and analyse the impact of assessment for learning on their students' motivation, engagement and learning.

\section{Conclusion}

This article has described the present-day situation in Omani schooling and the challenges it poses for teacher professional development. The study is based on a meta-analysis of a variety of studies, research reports, articles, and statistics with the aim of presenting a comprehensive picture of the challenges for the development of teaching and learning in Omani schools. The major concern is the low level of learning outcomes in Omani schools, but the policy aim is not only to raise the average level of outcomes but also to ensure that good learning outcomes are evenly distributed between genders, schools and regions. Gender is clearly a major issue for understanding schooling and teaching in Oman. A lot of the low performance of Omani boys is due to fact that teachers, especially male teachers, do not have a strong professional identity and commitment to teaching. Teaching as a professional career is not in high esteem among men in Oman. It is probably easier to enhance practical teaching skills than strengthen identity and commitment, but both are needed for productive teaching and successful learning.

The New Zealand Consortium report found evidence of relatively low morale amongst teachers in Oman. Among the factors affecting morale mentioned by teachers were "the impact of policy implementation upon working conditions, a negative narrative regarding the performance of teachers, salaries and benefits, 
and low levels of motivation through a lack of systematic recognition of teacher achievement". The report agreed that some of the initiatives being carried out by the Ministry of Education, such as providing more opportunities for professional development, should help improve teacher job satisfaction. However, to ensure that high performing teachers receive appropriate acknowledgment, mechanisms to provide recognition need to be developed. In particular, a teacher career structure should be developed in which promotion is linked to teacher performance and professional development (New Zealand Education Consortium, 2013).

Students, especially boys, often receive inappropriate feedback on the level of their skills and performance due to a defective assessment culture in Omani schools. Developing a new assessment culture which motivates students is fundamental for improving learning outcomes, and this new culture can be achieved through teacher professional development and supported by school principals and engagement with the whole school community.

The quality of school principals and the role they perform in their schools play an important role in improving student attainment levels (Louis, Leithwood, Wahlstrom, \& Anderson, 2010). However, the University of Cambridge report (2010) found "wide inconsistencies of practice between principals in their role as overall quality assurance managers of their own school". Traditionally in Oman, school principals were expected to simply act as the manager of the school building, spending most of their time on administration and adhering to Ministry rules and regulations. The Specialised Centre has developed a programme for school principals with the aim of bringing about sustained change in the way they operate in their schools. The focus of the programme is to promote the idea that school principals should be "leaders for learning" who aim to raise the quality of learning and teaching in order to promote better outcomes for students.

Not all failures and shortcomings we may find in schooling can be solved through teacher professional development or in-service training. Some of the shortcomings may be deeply rooted in socio-cultural traditions, while others depend on current economic factors. Definitely, teachers are not to be blamed for something over which they have no control. However, much can be achieved through concentrating on two factors: enhancing the status of the teacher profession and recruiting the most motivated students to be trained as committed teachers.

\section{Acknowledgments}

We thank Mr. David Griffiths for proof-reading the English language.

\section{References}

Al-Ani, W.T. (2014). Core values matrix of the philosophy of basic education in Oman (PBEO). Athens Journal of Education, 1(2), 167-181.

Al Balushi, S., \& Griffiths, D. (2013). School education system in the Sultanate of Oman. In G. Donn \& Y. Al Manthri (Eds), Education in the Broader Middle 
East: borrowing a baroque arsenal (pp. 107-125). Oxford: Symposium Books.

Al Belushi, A. (2004). Gender issues in teacher development: career choice and commitment in Oman. ELTED, 8, 16-27.

Al-Jardani, K. (2012). English language curriculum evaluation in Oman. International Journal of English Linguistics, 2(5), 40-44.

Al-Maskri, M.S., Al-Mukhini, S.H., \& Amzat, I.H. (2012). Improving education system in oman through school curriculum, teaching methods and evaluation: what is needed? International Journal of Sustainable Development, 3(10), 39-60.

Al-Sharbati, M.M., Al-Adawi, S., Al-Lawativa, \& Al-Hussaini, A. (2005). School failure: an exploratory observational study in Omani schoolgirls. Journal of Behavioural and Neuroscience Research, 3, 29-39.

Alsarimi, A. (2001). New trends in assessment in the sultanate of Oman: goals and characteristics. Educational Measurements: Issues and Practice, 27-28.

Al Shabibi, A. (2013). Omani English language teachers' first year in the classroom. $\mathrm{PhD}$ in TESOL, University of Leeds.

Alyahmadi, H., \& Al-Kiyumi, A. (2014). The consequences of teacher evaluation on teacher professional development in oman. International Journal of Education and Research, 2(4), 127-142.

Black, P., \& Wiliam D. (1998). Assessment and classroom learning. Assessment in Education, 4, 7-74.

Bourdieu, P. (1984). Distinction. A social critique of judgement of taste. Cambridge: Harvard University Press.

Breen, R., \& Jonsson, J.O. (2005). Inequality of opportunity in comparative perspective: recent research on educational attainment and social mobility. Annual Review of Sociology, 31, 223-243.

Centre for British Teachers (CfBT)/ National Foundation for Educational Research (NFER) (2012). Developing educational standards: benchmarking report. Muscat: Ministry of Education.

Chapman, D.W., \& Miric, S.L. (2009). Education quality in the Middle East. International Review of Education 55, 311-344.

Erikson, R., \& Goldthorpe, J. H. (1993). The Constant Flux: a study of class mobility. Oxford: Clarendon Press.

Erikson, R. \& Goldthorpe, J. H. (2002). Intergenerational inequality: a sociological perspective. Journal of Economic Perspectives, 16(3), 31-44.

Ermisch, J., Jäntti, M., \& Smeeding, T.M. (eds) (2012). From Parents to Children: The Intergenerational Transmission of Advantage. New York: Russell Sage Foundation.

Guskey, T.R. (1985). Staff development and the process of teacher change. Educational Researcher, 15(5), 5-12.

Guskey, T.R. (2002) Professional development and teacher change. Teachers and Teaching, 8(3), 381-391.

Guskey, T. R. (2003). What makes professional development effective? Phi Delta Kappan, 84(10), 748-750.

Hattie, J. (2009). Visible learning: A synthesis of over 800 meta-analyses relating to achievement. London: Routledge.

Ingvarson, L., Meiers, M. \& Beavis, A. (2005). Factors affecting the impact of professional development programs on teachers' knowledge, practice, student outcomes \& efficacy. Education Policy Analysis Archives, 13(10), 1-26.

Lareau, A., \& Conley, D. (2008). Social class: How does it work? New York: Russell Sage Foundation.

Louis, K.S., Leithwood, K., Wahlstrom, K. \& Anderson, S.E, (2010). Learning from 
leadership: investigating the links to improved student learning: final report of research findings. University of Minnesota and University of Toronto.

McKinsey \& Company (2010). How the world's most improved school systems keep getting better. Retrieved from http://bit.ly/2tZgGyV.

Ministry of Education (2008a). Educational development in Malaysia and Oman: Two Success Stories. Sultanate of Oman.

Ministry of Education (2008b). Inclusive education in the Sultanate of Oman: National Report of the Sultanate of Oman. Sultanate of Oman.

Ministry of Education (2009a). Education and cultural dialogue in the Sultanate of Oman. Sultanate of Oman.

Ministry of Education (2009b). Towards a sustainable world: Focus on education for sustainable development in Oman. Sultanate of Oman.

Ministry of Education (2016). Oman education framework for excellence; Draft [unpublished]. Sultanate of Oman.

New Zealand Education Consortium (2013). Evaluation of school system in Oman. Muscat: Ministry of Education.

OECD. (2005). Teachers matter: attracting, developing and retaining effective teachers. Paris: OECD.

Oman Population (2017). Retrieved from http://bit.ly/2v2eFih.

PIRLS. (2011). International association for the evaluation of educational achievement IEA. (2012). PIRLS 2011 International Results in Reading. Chestnut Hill: TIMSS \& PIRLS International Study Centre.

Pritchett, L. (2013). The rebirth of education: Schooling ain't learning. Washington: Center for Global Development.

Saunders, R. (2013). The role of teacher emotions in change: Experiences, patterns and implications for professional development. Journal of Educational Change, 14(3), 303-333.

Saunders, R. (2014). Effectiveness of research-based teacher professional development. Australian Journal of Teacher Education 39(4), 166-184.

Savage, M., Warde, A. \& Devine, F. (2005). Capitals, assets and resources: some critical issues. British Journal of Sociology, 56(1), 31-47.

Shavit, Y., \& Blossfeld, H.P. (eds.) (1993). Persistent Inequality. Changing educational attainment in thirteen countries. Boulder, CO: Westview.

TIMSS Math 2011. International association for the evaluation of educational achievement IEA. (2012). TIMSS 2011 International Results in Mathematics. Chestnut Hill: TIMSS \& PIRLS International Study Centre.

TIMSS Science (2011). International Association for the Evaluation of Educational Achievement IEA. (2012). TIMSS 2011 International Results in Science. Chestnut Hill: TIMSS \& PIRLS International Study Centre.

United Nations (2002). Arab human development report 2002. United Nations Development Program (UNDP). New York: United Nations.

United Nations (2010). Human development report 2010. The real wealth of nations: pathways to human development. United Nations Development Program (UNDP). New York: United Nations.

University of Cambridge (2010). Review and recommendations. Muscat: Ministry of Education.

Villegas-Reimers, E. (2002) Teacher professional development: an international review of the literature. Paris: UNESCO International Institute for Educational Planning.

Weis, L. (ed.) (2008). The way class works. Readings on school, family, and the economy. New York: Routledge.

World Bank (2012). Education in Oman: the drive for quality. Washington D.C: The 
Vol. 5, No. 3 Al Shabibi et al.: Challenges in Education System Affecting ...

World Bank. Retrieved from http://bit.ly/2t4EfSl. 